\title{
The Prospects for Catholicism in Russia*
}

\author{
SERGEI FILATOV
}

It is easy to point to facts indicating that there is no serious future for Catholicism in Russia. Catholics have very few congregations in comparison not only with the Orthodox but also with the Protestants. Although representatives of the Moscow Patriarchate talk continually about Catholic proselytism, the Catholics' preaching activity is very weak, and those who could be called missionaries are isolated individuals. Unlike Orthodoxy and Protestanism, Catholicism was virtually wiped out during the Soviet era in Russia. The Vatican itself is apparently bowing to pressure from the Moscow Patriarchate and 'voluntarily' restricting its activity to within tight limits. Considering all this, the title I have given my article might seem an empty provocation. There is more evidence of future prospects for Protestantism. However, I want to draw attention to some very important features of the contemporary worldview of the Russian people, some peculiarities of current religious belief, and some political and cultural orientations prevailing in society today, all of which permit us to say that there are very great opportunities for Catholicism and that the soil is extremely well prepared for it. In this article I will be using the results of three allRussian sociological surveys on the post-perestroika worldview of the people of Russia, which I carried out in 1990, 1991 and 1992 with my assistant Dr Lyudmila Vorontsova; but I think that the patterns we observed could be deduced not only from sociological surveys, but also from careful observation of the social and religious life of Russia today.

To begin with, how do our contemporaries identify with religious labels? We put the question 'What do you consider yourself to be?' and we suggested the following answers: 'Orthodox', 'Baptist', 'Catholic', 'Old Believer', 'Buddhist', 'atheist' and 'just Christian'. Amazing as it may seem, in 199252 per cent of the Russian urban population replied that they were 'just Christian'. In other words, they consider themselves to be Christians, but they refuse to be linked with any specific confession. For many people, of course, this sounds scandalous - why should people not call themselves Orthodox? It is a staggering fact, and to begin with I did not believe these results myself. One automatically begins to look for some sort of explanation which would solve the problem quite simply, and within the framework of traditional concepts. When we analysed the replies of people from various social groups, we saw that a significant percentage among the inhabitants of small towns, the elderly and those with little education were calling themselves 'just Christians'. It is clear that these people are not influenced by any new ideological trends and that from a religious

*This article is a revised version of a talk given at the conference 'Orthodoxy and Catholicism Face to Face with Contemporary Culture' (St Petersburg, 15-16 May 1992). 
point of view they are completely traditional folk. It is possible to conclude that some traditionally Orthodox people call themselves 'just Christians'. But not only does this not explain everything, it does not explain the most important thing: the fact remains that the majority of these 'just Christians' are educated young people living in large towns. And the most significant thing of all is that the percentage of 'just Christians' grew from 22 in 1990 to 42 in 1991, and in 1992 it reached 52. This explosive growth in the numbers of 'just Christians' cannot be explained in terms of the answers given by traditional Orthodox believers. In that case the number of 'just Christians' would not have grown at all. If we analyse many other facets of the modern Russian religious mind-set, however, we come to the conclusion that this is a quite natural response. Where do most people get their religious convictions from? Where do they get their religious information? Our surveys show that the main sources of religious convictions and religious information are the mass media, works of fiction and conversations with relatives and friends; specific church sources occupy a very modest place. ${ }^{1}$ The label 'just Christian', then, reflects the real state of the current Russian religious mind amorphous, spontaneous, eclectic.

The second important factor determining the prospects for Catholicism is linked with a number of cultural phenomena. Even ten years ago, just as for centuries before, Russians were conscious of standing over against the West. Distrust, dislike and lack of understanding of the West were reinforced by both the tsarist and the Soviet regimes, but were already embedded in the Russian soul. Russians did not like or understand the West, and they did not like or understand its faith. An analysis of sympathy and antipathy towards different nations would show that, say, twenty years ago (and probably two hundred years ago as well) western nations such as the Germans, the English and the Americans evoked much less fellow-feeling than our own compatriots such as the Kazakhs, Georgians and Tatars. Now everything is the other way round. Today our favourite nations are the English, the Germans and the Americans, while towards the Caucasian and Central Asian people our level of intolerance is very high, and rising continually.

The beginning of perestroika was marked by euphorically pro-western attitudes. Western values and western standards of living (however badly we understood them) were taken as a kind of norm for Russia. Many thoughtful observers remarked that this state of affairs could not last for long. There would have to be a nationalistic reaction; the search for identity would inevitably lead to the rise of negative feelings towards the West. In 1992 we saw just such a turnabout. In particular (and we could cite further examples) surveys show that from 1992 onwards there was a sharp drop (from 38 to 14) in the percentage of people who affirmed that 'western countries offer the best possible society today; we should not try to work out our own ways, but rather follow the West'; and there was a sharp rise (from 49 to 71 ) in the percentage of people who thought that 'we are a very individual country, and we should seek our own paths of development'. But these same surveys revel real limits to this ideological about-turn: there is a continuing growth in the number of people who subscribe to the principles of human rights, democracy and the market economy - generally now more than twothirds of the population on any of these questions. There is even a continuing growth in positive feeling towards western nations. The results of the surveys, at least those carried out most recently, bear witness to the fact that the search for national identity is being pursued within the framework of western values and concepts.

How do these general ideological positions reflect on attitudes to western religious confessions? After all, a general ideological orientation towards western values must penetrate into all cultural and ideological spheres. One would naturally expect to see 
sympathy towards western confessions, especially considering the spontaneous and eclectic nature of the popular religious consciousness. The surveys confirm this supposition. Apart from Orthodoxy, the most popular confession is Catholicism. Moreover, Catholicism enjoys more popularity among people who consider themselves Orthodox than among the population as a whole. In 1992 it was obvious that Russians were in a process of searching for their own identity. There was a drop in the popularity of Buddhism and Protestantism, but not of Catholicism.

But why Catholicism and not Protestantism?

The first possible reason that naturally comes to mind is that Catholicism is hierarchical and authoritarian, and is thus near to the Russian Orthodox understanding of the church, whereas Protestantism is more alien and incomprehensible to Russians. In prerevolutionary times, however, the situation was reversed: there were very few conversions to Catholicism; it evoked almost universal distaste. At the same time the Baptists and Protestant sects in general experienced quite a dramatic growth. At that time, leaving the Orthodox Church was usually linked precisely with distaste for an authoritarian, hierarchical church.

The real reason, then, is I believe to be found elsewhere: in the fact that our religiosity has become more of an aesthetic and cultural phenomenon. If we ask, 'what meaning do art and literature hold for you?', around 70 per cent reply that for them they hold a religious significance. And if we ask whether or not priests should understand and be well-versed in literature and the arts, then 80 per cent answer that this is a necessary requirement for the priesthood. The clergy and the church are considered to be some kind of cultural force. It is possible that the support for the return to the Moscow Patriarchate of icons and other medieval objets d'art from museum collections may be a Pyrrhic victory for the Patriarchate, with people looking on the church as a cultural institution, some sort of 'proper' museum. If people regard religion as some sort of cultural phenomenon, then, it is natural that Protestantism, which does not have such deep ties with European culture and history, should have less chance of evoking universal interest and sympathy. Another reason why Protestantism is losing popularity is precisely because it is familiar to Russians. Many years of propaganda about the Baptists, depicting them as hypocritical, intolerant and ignorant sectarians, have left a definite impression on the popular mind.

Looking at the aggressive and hostile position of the Moscow Patriarchate with respect to Russian Catholicism, we have to ask the question: whose opinions is it expressing? Sociological surveys have difficulty pinpointing that section of society, represented by church bureaucracy and a narrow band of the 'church community', which traces its immediate history back to the 'concordat' between Stalin and Metropolitan Sergi (Stragorodsky), but has deep roots in Russian history. However, popular Russian religiosity today has very little to do with this tradition. This religiosity is born out of the logical evolution of popular consciousness, the elemental development of which began after the collapse of communist ideology. For this reason we should not unthinkingly accept at face value what representatives of the Moscow Patriarchate say about the threat of social conflicts caused by the spread of Catholicism. The Moscow Patriarchate usually points to the Western Ukraine as a likely example of what could happen in Russia. But Russia is not Galicia. We do not have ethnic groups locked in national and religious conflict going back for hundreds of years. In Russia we have a totally different religious consciousness, and I have indicated some of its main characteristics in this article. The level of religious intolerance in Russia today is generally very low and towards Catholicism, as I have already indicated, it is least of all. The highest - and rising - level of intolerance is towards Islam. Thus when they 
suggest that any penetration of Catholicism into Russia could lead to some kind of social conflict, it shows that they have not understood the contemporary Russian religious mind.

Does the presence of Catholicism in Russia, then, really pose a danger to the Moscow Patriarchate? It seems to me that when Aleksi II speaks about Catholic penetration as if it were more or less the main danger for Orthodoxy, he is making a mistake typical of a representative of a ruling church in the face of the spread of religious minorities. I could cite dozens of historical examples demonstrating the political shortsightedness of such an approach. The Catholic Church in France before the Revolution did everything in its power to fight the Calvinists and any other Protestants. The Catholic hierarchy saw them as the main danger; but it ended up with the anticlerical Jacobins who were a hundred times more dangerous than any Huguenots. Everybody knows how the ruling Synod under the tsarist regime fought with the Baptists and the Old Believers. But the Orthodox hierarchy ended up with the bloody terror of bolshevism.

It seems to me that the Russian Orthodox Church today should be spending more time preparing for a new wave of anticlericalism: this is what represents the greatest danger. For the evidence shows that the honeymoon that began for Orthodoxy and the Russian people in 1988 is coming to an end. This is an objective process. A church which had for so long been in a state of subjection had not developed the language, the personnel or anything else which would have been essential in order to talk to society today. Naturally it was incapable of responding to the passionate surge of the people towards the Orthodox Church. Surveys carried out in 1992 show that trust in the Patriarchate had decreased - but when will the Patriarchate be able to respond? It is clear that this will not be within one year, or even two or three. The people are not going to wait for long. Disenchantment today will not be as bloody as it was in 1917, but all the same the outcome will be an unpleasant experience for the Russian Orthodox Church.

Meanwhile, Catholicism is present in Russia with organisational forms and intellectual ballast which could provide examples for Orthodoxy to work through creatively. The very existence of a Catholic element could soften the blow of a new anticlerical wave. In many cities where there are no Catholic parishes, surveys reveal that 1-2 per cent of the people consider themselves Catholics. These are spontaneous, self-styled Catholics, who have no connections with a church. There are even more 'Catholics' among Russian young people and the intelligentsia of Moscow and St Petersburg. You can now find Catholics in almost any higher educational institution in both capitals. Russian Catholicism is taking shape without regard for what anyone may have decided.

\section{Notes and References}

1 The actual figures behind these assertions appear in Vorontsova and Filatov, 'Freedom of conscience in Russia: what the opinion polls show', Religion, State and Society, vol. 21, nos $3-4,1993$.

(Translated from the Russian by Cathy Carter.) 